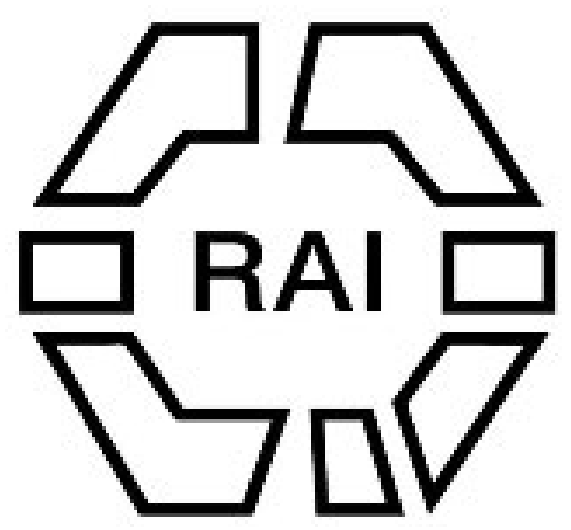

Notes on the Ethnology of Tribes Met with During Progress of the Juba Expedition of 189799

Author(s): J. R. L. MacDonald

Source: The Journal of the Anthropological Institute of Great Britain and Ireland, Vol. 29, No. 3/4 (1899), pp. 226-247

Published by: Royal Anthropological Institute of Great Britain and Ireland

Stable URL: http://www.jstor.org/stable/2843005

Accessed: $15 / 06 / 2014$ 03:13

Your use of the JSTOR archive indicates your acceptance of the Terms \& Conditions of Use, available at http://www.jstor.org/page/info/about/policies/terms.jsp

JSTOR is a not-for-profit service that helps scholars, researchers, and students discover, use, and build upon a wide range of content in a trusted digital archive. We use information technology and tools to increase productivity and facilitate new forms of scholarship. For more information about JSTOR, please contact support@jstor.org. 


\section{NOTES ON THE ETHNOLOGY OF TRIBES MET WITH DURING PROGRESS OF THE JUBA EXPEDITION OF 1897-99.}

\section{By Lieut.-Colonel J. R. L. Macdonald.}

DuRING the travels of the expedition which I had the honour to command, we came in contact with between thirty and forty native tribes, and were able to collect a serics of notes on their languages, customs, and traditions, meagre indeed, but still of interest. In some cases the information is new, and in others it tends to support the views of previous travellers, or modify their speculations by the provision of additional data. The expedition had neither the time nor the scientific training necessary for the task of solving the many most interesting problems regarding the true classification and grouping of these various tribes in the general scheme of the African races, or of tracing the various migrations that must have led them to their present geographical distribution. That must ve left to experts, and the expedition will be content if it has supplied a few additional facts to guide the experts to the solution of the problems.

The regions, in which the labours of the expedition lay, are singularly interesting from an ethnological point of view, comprising as they do the meetingplace of several great African families, the Bantu, the Negro, the Hamitic and the Masai or Nuba-Fulla. In endeavouring to compile a few notes that may be interesting, I would purpose to consider the language, customs, etc., of the tribes encountered in five groups, without prejudice to their ultimate inclusion in any of the great African races. The grouping I propose for the purpose of this paper is one that I was led to adopt from the apparent connection of the tribes, and whether or not it may be scientifically accurate, it is at all events convenient, as whatever race the group may be ultimately included in, it will probably carry with it all its component members. This grouping is as follows:-

\begin{tabular}{l|l}
\multicolumn{1}{l|}{ Nuba-Fulla? } & Langu. \\
Masai. & Rom. \\
Kwafi. & Lango or Wakerli. \\
Sambur or Kore. & Umiro. \\
Latuka. & Kimama. \\
Karamojo. & Wahima? \\
Turkana. & \\
I.)onyiro. & Suk. S'uli? \\
Elgumi. & Nandi.
\end{tabular}




\section{I.-MAP OF UGANDA AND ADJOINING TERRITORIES ILLUSTRATING THE PRESENT DISTRIBUTION OF THE ALLIED TRIBES \\ By J. R. Macdonald, Lt. Col.}

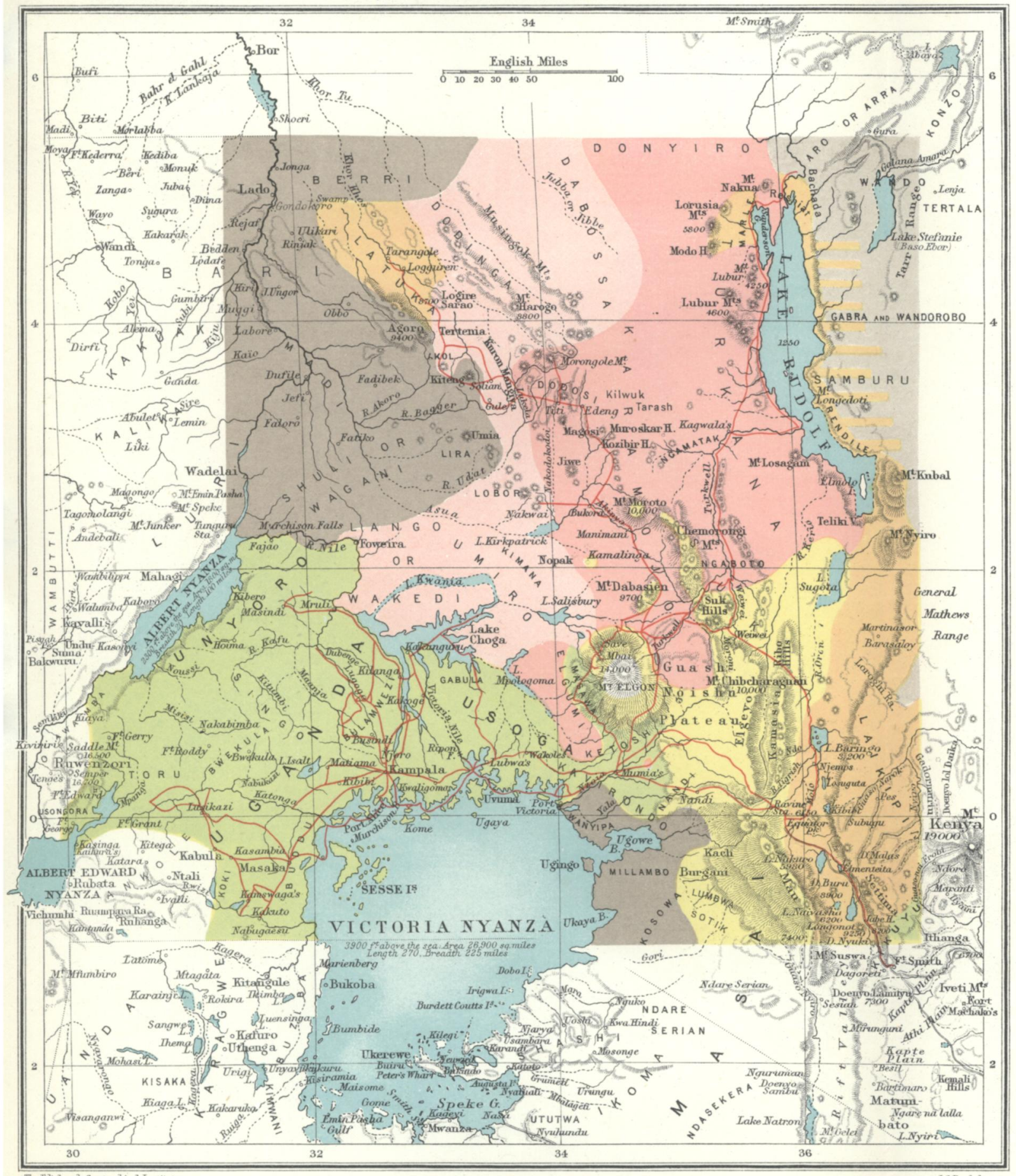

\section{EXPLANATION OF COLOURING}

\begin{tabular}{|l}
\hline Karamojo \\
\hline Lango Tribes \\
believed to be allied \\
to the Karamojo \\
Masai and Latuka
\end{tabular}

\begin{tabular}{|l}
\hline \\
\hline Suk-Nandi Group \\
\hline Bantu \\
Somali, etc.
\end{tabular}

The relative territoru of Eloegon. Suk-Nandi. and Karamoio is probablu fairlu reliable 
ILLUSTRATING THE PRESENT DISTRIBUTION OF THE ALLIED TRIBES

By J. R. Macdonald, Lt. Col.

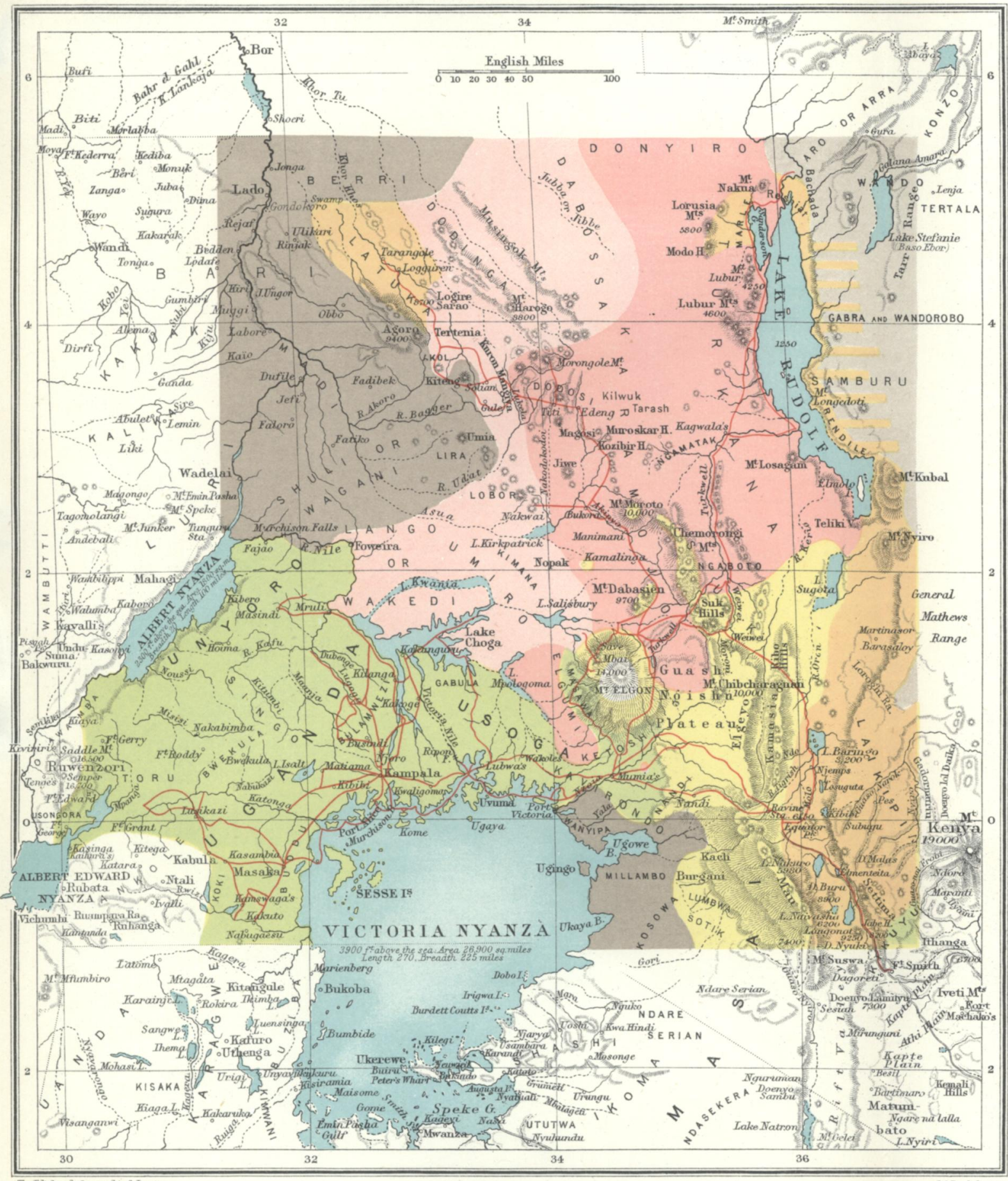

EXPLANATION OF COLOURING

\begin{tabular}{|l|}
\hline Karamojo \\
Lango Tribes \\
believed to be allied \\
to the Karamojo \\
Masai and Latuka
\end{tabular}

\begin{tabular}{|l|l}
\hline & Suk-Nandi Group \\
\hline & Negro \\
\hline & Bantu \\
\hline & Somali, etc.
\end{tabular}

The relative territory of Eloegop, Suk-Nandi, and Karamojo is probably fairly reliable

The contemporary distribution of the Lango, Bantu, and Negro Tribes as shown is however uncertain, and is here to be considered as only a suggestion

Route of Col. Macdonalds' Expedition shown thus:- 


\section{II.-MAP OF UGANDA AND ADJOINING TERRITORIES ILLUSTRATING FORMER EXTENDED DOMINION OF THE ELOEGOP (MASAI)} By J. R. Macdonald, Lt. Col.

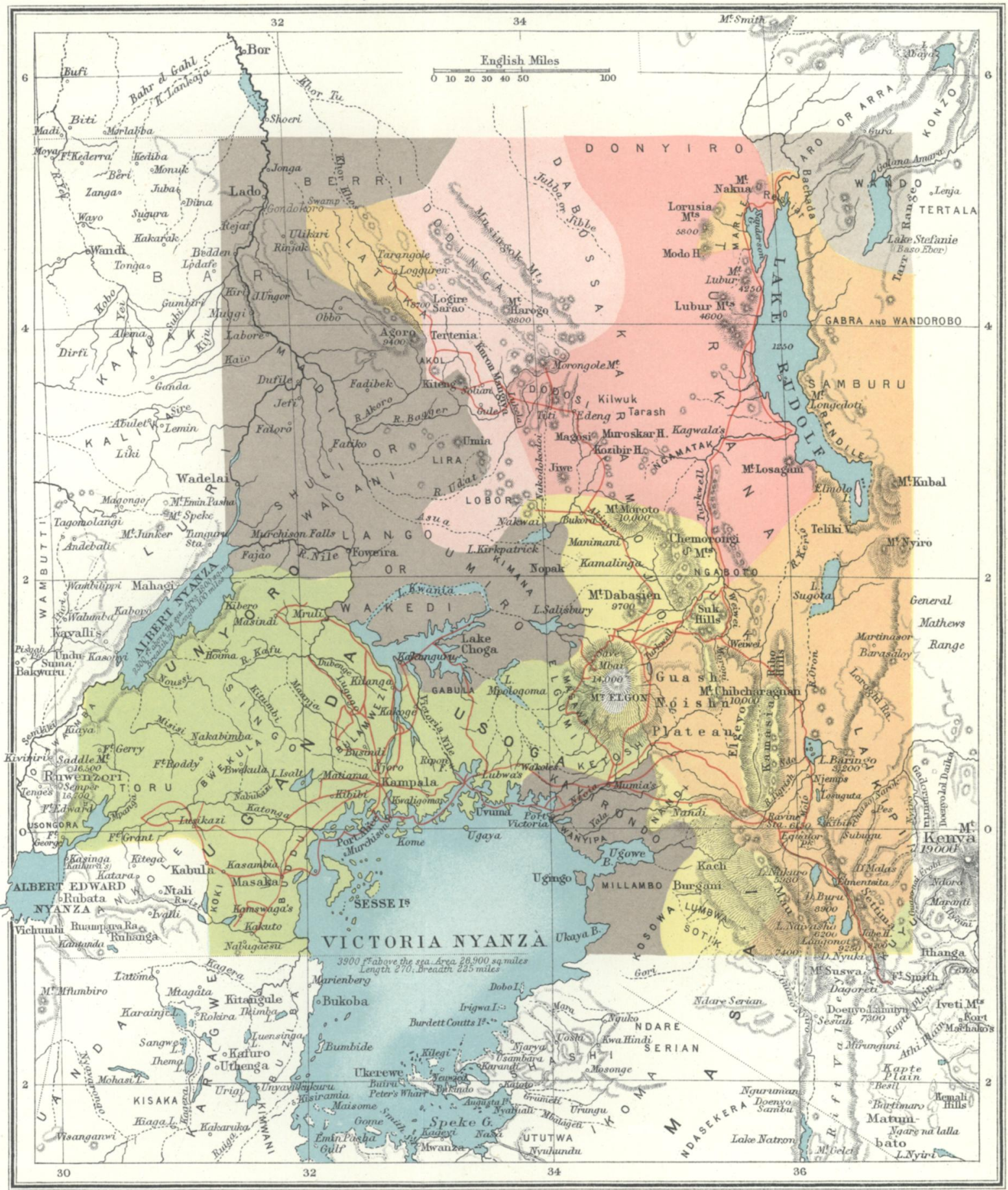

The Ediuburght Geographical Institute

EXPLANATION OF COLOURING

$\square$ Karamojo
\begin{tabular}{|l}
\hline \\
Lango Tribes \\
believed to be allied \\
to the Karamojo
\end{tabular}
Masai and Latuka

$\square$ Suk-Nandi Group
Negro
$\square$ Bantu
Somali, etc.

The relative territoru of Eloeaon. Suk-Nandi. and Karamoio is nrobablu fairlu reliable 
ILLUSTRATING FORMER EXTENDED DOMINION OF THE ELOEGOP (MASAI)

By J. R. Macdonald, Lt. Col.

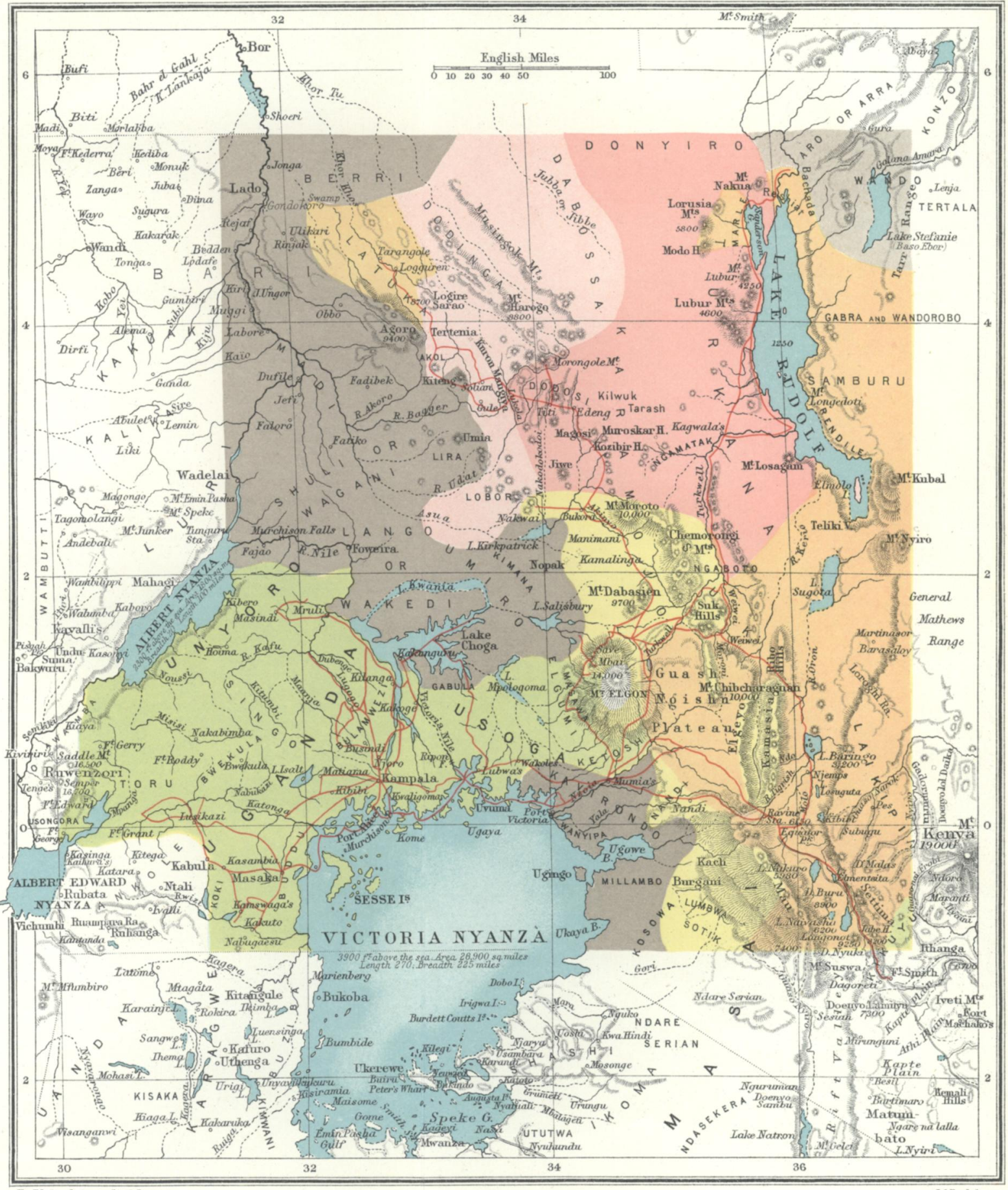

EXPLANATION OF COLOURING

$\square$ Karamojo
$\square$ Lango Tribes
believed to be allied
to the Karamojo
Masai and Latuka

$\square$ Suk-Nandi Group
Negro
$\square$ Bantu
Somali, etc.

The relative territory of Eloegop, Suk-Nandi, and Karamojo is probably fairly reliable

The contemporary distribution of the Lango, Bantu, and Negro Tribes as shown is however uncertain, and is here to be considered as only a suggestion

Route of Col. Macdonalds' Expedition shown thus :- 


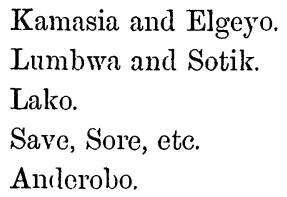

Bantu.

Wagandu.

Wasoga.

Wanyoro.

Watoru.
Wakavironciu.

Waketosh.

Masowa.

Negro.

Shuli.

Nyifa or South Kavirondo.

Madi.

Bari.

Beri.

Many of these tribes have been so fully dealt with by others that they need not be further referred to here, but the remaining tribes I propose to deal with by first (a) Considering the connection in language; (b) furnishing some information regarding their habits and customs; and (c) giving a few brief notes on their history as it could be obtained from their own traditions or deduced from those of their neighbours.

\section{(a.) Comparative Vocabularies.}

The comparison of languages by means of meagre vocabularies is unsatisfactory in many respects; but in the case of an expedition which travels rapidly and cannot afford the time for the construction of grammars, the comparison by vocaloulary is the only one possible.

It must, however, be remembered that the vocabularies collected by the expedition were not taken from slaves at a distance from their own countries, but were in almost every case the result of actual travel amongst the tribes concerned.

Comparative vocabularies of twelve languages, in addition to Swahili (the general medium of conversation), are attached. Of these twelve, two, the Ogaden Somali and Borana Galla, were taken down from Somalis who accompanied the expedition for purposes of comparison with the other languages; as they may be of interest I have allowed them to stand in the tables accompanying this paper. Each vocabulary given shows about 108 words. Unfortunately Mr. C. Hobleyr, who had collected vocabularies of certain languages, could not furnish me with a list of the English words he used, and so only some forty words are common to his and my own vocabularies; still this is better than nothing and renders the two sets of vocabularies mutually useful.

The expedition vocabularies embrace the languages of the following tribes:Usoga, North Kavirondo, Masai, Karamojo, Latuka, Nandi, Anderobo, Save, Suk and South Kavirondo. The people of Kamasia and Elgeyo talk the same language as the Nandi, and the Turkana and Donyvio have the same language as the Karamojo.

Mr. C. Hobley gives vocabularies of the following:-North Kavirondo, Muhasa, South Kavirondo (Nyifa or Nife), Elgumi, Nandi, and Lako. 
As already stated some forty words are common to both sets of vocabularies, so we can, to this extent, construct a comparative vocabulary of the languages talked by some fifteen of the tribes in the area under discussion. Casati's vocabulary of Lur, which is stated by Emin to be closely allied to Shuli, has a good many words common to one or other set of vocabularies, and shows that South Kavirondo is allied to those languages; and as the Kwafi and Samburu languages are merely dialects of Masai, we may say that we can to some extent extend our comparison over nineteen languages.

With regard to the expedition vocabularies care was taken by questioning several men to secure accuracy in obtaining the correct corresponding word. That this was invariably successful is hardly probable; but still it is hoped that the results of our efforts towards strict accuracy will be found fairly reliable.

The vocabularies of Usoga, North Kavirondo, Masai, Karamojo, South Kavirondo, and Suk were obtained direct from natives of these tribes; the languages of the Nandi and Anderobo were got from a Suk Government interpreter; the Save vocabulary was taken down from a Swahili who had been long resident in the district and knew the language well; while the Latuka was from the Latuka Soudanese who had been some time in that country and had Latuka wives. Kiswahili was the medium of communication in every case except Latuka when Arabic was employed.

The words have been written in English characters as nearly phonetically as possible, but in dealing with savage languages and unfamiliar sounds it is very difficult to express the exact sound in English characters. The "l " and " $r$ " are practically interchangeable in many cases, and the sounds of " $p$ " and " $d$ " may almost imperceptibly slide into " $\mathrm{b}$ " and " $\mathrm{t}$," while the hard " $\mathrm{g}$ " and " $\mathrm{k}$ " are frequently nearly alike. Again there are some nasal sounds in Masai, Karamojo and allied languages that are difficult to express; these have been shown by "ng" or " $n$ " as most nearly representing them.

We may now glance at the general results, Masai, Kwafi (or more properly Guash Ngishu, for Kwafi is a Swahili term), and Sambur (or Kore) are three divisions of the one tribe, the Eloegop, and speak what may be considered one language with slight dialectic differences. This was noticed by Farler, as regards the two first-mentioned, from vocabularies made out by missionaries before Masailand was actually visited by Europeans. Extensive vocabularies of Masai and Kwafi have been compiled by Krapf and Erhardt, and Cust groups this language with the Nuba-Fulla.

We found that the language most nearly allied to that of the Eloegop, though widely separated in geographical position, was that of Latuka in the Nile Basin. The classification of this language had previously been a matter of dispute. Cust in his Modern Languages of Africa places it in the Negro group, but notes that Baker in his Nyanza remarked that it was quite distinct from that of the Nile tribes he niet. Baker was inclined to think that the people of Latuka were Gallas, while Emin placed them among the Langos, whom Cust classes in the 
Hamitic group, and Ravenstein in 1884 from Emin's vocabulary considered the Latuka were Masai. The Latuka can hardly be called Masai, but the great similarity of their languages, extending as it does to some thirty per cent. of the words, would appear to show a common origin.

The Latuka and Eloegop must, however, have been separated for a long interval as there are marked differences in the intonation of certain words, the Latuka being on the whole the softer language.

Closely allied to the language of Eloegop and Latuka, but with rather more divergence, comes that of the Karamojo Turkana and Donyiro, which has, however, sufficient similarity to indicate a common origin. It is noticeable that the syllable "ak" which begins so many Karamojo words is not so very different in sound, as might be supposed by the spelling, from the "ng" which appears in Masai, the " $\mathrm{g}$ " of which is very hard and almost " $\mathrm{k}$ ".

I was unable to get a comparative vocabulary of Elgumi, but fortunately Mr. C. Hobley secured one, and this shows that the language of the Elgumi may be considered a dialect of Karamojo. I may here mention that Elgumi is a name applied by the Masai not only to the tribe west of Mount Elgon but also to the Turkana and possibly to the Karamojo. It is not a name recognised by the tribes themselves, and would appear to be a nickname applied by the Masai to their tribes on account of their well-developed noses. The term Elgumi is thus somewhat indiscriminately used by the Masai for the Karamojo tribes, in the same way as "Lango" is used by the Nile tribes to the west to designate the same people.

We thus find the Masai, Guash Ngishu (or Kwafi), Sambur (or Kore), Latuka, Karamojo, Turkana, Donyiro and Elgumi speaking languages which would appear to clearly indicate a common origin.

So far we have been on fairly solid ground, but with regard to the other tribes I have provisionally placed in the same group, information at our disposal is hearsay. The people of Langu and Rom were visited by the expedition, but vocabularies were not collected. We were, however, told by our Karamojo guides that these small tribes were allied to themselves and spoke a nearly identical language. I am inclined to think the same thing applies to the Lango or Wakedi, the Umiro and Kimama. It is doubtful whether these last names do not refer to one and the same tribe. The Karamojo know the powerful tribe dwelling north of Lake Salisbury as the Kimama and say their territory extends far to the west. They do not know the term Lango or Wakedi and appear to know little of Umiro. The territory they ascribe to the Kimama would appear to be so extensive as to embrace a considerable portion of the country which is said by the Waganda, Wangoro and Shuli to be occupied by the Lango and Umiro. I have already pointed out that "Lango" is a far-reaching term as employed by the Nile tribes and is used to embrace the Karamojo themselves. Wakedi or Bakedi (the naked people) is simply a Luganda and Lungoro nickname applied to the Lango. I an accordingly inclined to think that the tribe might be called Umiro and that the 
Umiro are known on the east as Kimama and on the west as Lango. They would, however, appear to be allied in language to the Karamojo, but it appears to me that they are not a pure bred tribe, but an admixture of Karamojo and Nilotic and perhaps aboriginal blood. It is to be noted that while the Elocgop, Latuka, and Karamojo are largely pastoral and dwellers on the more open plains, the peoples of Rom, Langu, Umiro and Lango are for the most part highlanders, while the Kimama are dwellers in swainpy country. Still the balance of evidence would seem to show that these last mentioned tribes are more or less allied to the Karamojo group.

This latter group would appear even more extensive, as our Swahilis told us of another tribe nortl of Karamojo called Dabosa which speaks the saine language as Karamojo, and the Dodinga (or Irenga) tribe would also appear allied to this. The group of languages we have so far considered are apparently connected to the cxtent of 30 or 40 per cent. of their words, but now we come to another group, the Sul-Nandi, which, while possessing a still larger percentage of words common within the group, has comparatively a small percentage of words which appear in the languages of the Masai group. The percentage is lowest, about 5 per cent., in the case of the Latuka, which is geographically most removed, and rises to about 11 per cent. in Masai and Karanojo, which are conterminous with the Suk-Nandi country. It is interesting to note that the group now dealt with has almost the same percentage of words common to the language of Ogaden Somali, a Hamitic family.

It had previously been noted that the Nandi, Lumbeva and Sotik were the same, or a clearly allied people, and more recently that of Nandi Kamasia and Elgeyo tribes appeared identified. Mr. C. Hobley, to whose study of the languages of his district we owe so much, further established a close connection between the Nandi, Lako and Save. It was, however, left for the expedition not only to confirm Mr. Hobley's deductions, but also to bring into the same group the Suk, and an even more interesting fact, the Anderobo, formerly classed as a Helot tribe.

With the exception of the Anderobo, who are Helots to the Masai and are admitted by their masters to have been the original inhabitants of Central Masailand, the remaining tribes of this group are mountaineers, who not only possess what is almost a common language but who also show a great similarity in many of their customs.

These connections, together with the present geographical distribution of the tribes and their own legends, would show that they form fragments of a large tribe, which occupied an extensive tract of Masailand and South Karamojo prior to the advent of the Eloegop. This is further confirmed by the inclusion of the Helot Anderobo in the Suk-Mandi group of languages. The northern members of the group show more connection in loan words with the Karamojo, the southern members with the Masai, and this is in harmony with the tribal traditions to the effect that they were respectively partially dispossessed by Karamojo and Eloegop. 
A further interesting fact in this connection is that the Suk headdress favour the Karamojo as the Mandi one does the Masai.

The well-marked Bantu group need not be dwelt on. But it may be interesting to note a few points regarding Ketosh and Masawa. I have called the Bantu tribe north of the Nzoia River and south of Mount Elgon Ketosh, and confined the term Masawa to the region west of Mount Elgon. It must however be understood that Masawa is sometimes used in a wider sense to embrace Ketosh, and that the inhabitants of both regions would appear to belong to one tribe or to be very closely related. Mr. Hobley, who first established that there were Bantu speaking people on the west of Mount Elgon, was inclined to show a wedge of Elgumi separating what I call Masawa into a northern and a southern portion. During our journey to the west of Mount Elgon, however, we found tribes he had classed with the Elgumi; the Ngoko, for instance, were Bantu, and on discussing this point with Mr. Hobley on our return he was inclined to agree with us that the western slopes of Mount Elgon might all be classed as Bantu. The people of Ketosh and Masawa, though they have much in common with the Bantu Kavirondo, have certain marked resemblance to the Wasoga, and it is interesting to find that the language of Usoga would appear to bear a far closer connection with Masawa than with North Kavirondo.

Of the Negro group of tribes I have little to say. Mr. Hobley had already established the fact that the people of South Kavirondo or Nyifa (Nife) belonged to this group, a fact borne out by the connection between the Nyifa and Lur vocabularies. The Lur and Shuli languages are closely connected, as has been pointed out by Emin, who also found they were so closely related to Shilluk, that his Shilluk soldiers could easily make themselves intelligible to the Shuli. The Bari and Beri are supposed to be connected with the Dinka, and the Madi with the Nyambara (Cust) or Makaraka.

There are evidently fragments of still older tribes scattered about in this great area the study of whose languages would be interesting. Thus the Lako, Save and Masawa told us of a small scattered tribe, called the Elgonyi, who dwell on the upper slopes of Mount Elgon. Similarly the people of Latuka said that amongst the lofty mountains south-west of the Latuka valley, there were a number of small tribes with a language differing from that of the Latuka and Nile tribes. Donaldson Smith found a small separate community called Dume, north of Lake Stephani; and Austin was not able to connect the Marle north-west of Lake Rudolf with the surrounding tribes, though they bore some resemblance to the Masai or Sambur.

\section{(b.) No'ces of Customs of Various Tribes.}

The Masai group including the whole of the Eloegop, the Latuka, the Karamojo, Turkana, Donyiro, and Elgumi are, for the most part, pastoral dwellers in open grass plains. Agriculture is, however, practised to some extent more especially in Latuka, Karamojo and Elgumi. With the one exception of Latuka, 
where there is a recognised king, the remaining members of the group are split up amongst a number of petty chiefs, who, however, combine in case of war. Internal strife is, for the most part, avoided by strict laws regarding the settlement of disputes; this has, however, become rather lax amongst the Eloegop, who have in consequence become much weakened by civil war and are fast losing their power.

The members of this group dwell in considerable villages or groups of villages, permanent and large in the case of Latuka, semi-permanent in the case of Karamojo and Elgumi, and movable amongst the Eloegop and Turkana.

It is doubtful what is the religious belief of the Latuka, but the other members of the group believe in one Supreme Being and in a future life, though there is also a belief in the power of rain and locust doctors.

There is amongst all much the same general organisation for war, and two fighting chiefs are appointed on mobilization. The fighting weapons are spear and shield; bows and arrows are hardly used at all. A few old men amongst the Masai possess these weapons, but poison is not employed. The northern members of the group, however, use the throwing spear as a missile. All the members of the group are brave and courageous and are much feared by their neighbours. They are, however, open and manly, and not given to treachery as a rule.

The tribes to the west, whom I have already mentioned as being probably of mixed origin though allied to the Karamojo, are more agricultural and dwell in more difficult country. They also appear to be more treacherous, but use much the same weapons as the Karamojo.

The knowledge of working iron, dressing hides, and making pottery is universal. The males are, for the most part, naked; the females more or less decently dressed.

In view of the recent medical theory on the connection between mosquitos and malarial fever, it is interesting to note that amongst some members of the group it is a well-established article of belief.

The following more detailed account of the customs, etc., of the Masai and Karamojo are given :-

\section{Masai.}

The men are mostly tall, the women of medium height. The hair is woolly. Prognathous features are never seen. Their muscles are not, as a rule, welldeveloped, but they are active.

Mode of Subsistence.-Mainly by pastoral pursuits. Cooking is primitive when obliged to eat vegetable food, this is prepared by boiling; but they live, when possible, on milk and meat, the latter raw, or nearly so.

Their huts are little more than dome-shaped shelters, either thatched or covered with hides, each with a small door. A collection of huts is enclosed by a thoin zareba. If obliged by scarcity of cattle, sheep, or goats to take to agriculture, they grow millet.

Religion and Customs.-A young man is not supposed to marry until he has 
hlooded his spear. He sends a jar of honey or small present to the parents of the girl he wishes to marry. If they accept this, it is a sign his suit is approved of. He then sends four oxen, and three goats, and the bride's mother brings the girl to his hut, where the bridegroom has milk in readiness. The bride refuses to enter until she is given a goat. There is no ceremony, but the bridegroum wears the bride's skin petticoat, smeared with fat and red earth for a month after marriage. There is no limit to the number of wives. A wife who misconducts herself three times may be returned to her parents, who refund the present received from her husband.

Women with child are fed on light diet. After birth both mother and child are given the fat of goats, and a mixture of blood and milk. The first appearance of milk teeth on the left before the right is considered a bad omen. A child is named after two months. On death a chief may be buried; lesser people are carried outside the kraal and left to the hyenas.

The Masai believe in one Supreme Being, called "Ngai," and in a future state. The Supreme Being is always invoked for success on the war-path.

Before starting on the war-path, the Leibon is consulted, and medicine inade. The warriors then, for some time previous to the start, retire into the jungle and eat flesh, which is supposed to make them fierce.

Two fighting chiefs are selected, and the war party assembles. An ox is then killed, and the Leibon makes a fire; each warrior lights his fire from the central one, and after the ceremony is irrevocably committed to the war-path.

In dividing spoil, a place is selected some four days' march from home. The war party then select nine men as arbitrator's, all of whom must be good warriors. These arbitrators then call out the warriors one by one, and allot to each his share. If any man objects, his objection is considered, and, as an ultimate resort, he fights one of the arbitrators, with knobkerries and shields as a rule. If he fails to defeat the arbitrator, he gets nothing; if he kills him, he is himself put to death.

If in peace a man kills another, all his cattle are given to the victim's father. If he wounds another, nothing is done if the wounded man recovers; but if he is permanently disabled, a fine of oxen up to nine is paid.

In settling serious disputes by oath, each disputant takes hold of a goat or sheep, which is then cut in two. This is done in presence of witnesses, and the matter thus settled is not supposed to be reopened.

A minor oath as to a statement is taken by biting a piece of grass.

Arts and Manufactures. - Raw hide is made into shields and scabbards, and used for clothing.

Tobacco is smoked in pipes or used as snuff.

A fermented liquor is made from millet.

Their ironwork is manufactured for them by their subordinate Wanderobe.

Personal Ornaments.-The lobule of the ear is pierced and enormously distended; they wear a cylindrical block of wood in the aperture. 
The hair of both sexes is plastered with grease and wet clay, and plaited into a number of small tails.

An operation resembling circumcision is practised on the men, and a special mutilation on the women.

The ordinary dress of the men consists of one or two goat-hides; they have no idea of decency; but the women are well covered with similar hides.

Both men and women plaster the body with grease, generally nutton fat, and red clay. The married wornen shave their heads; they also wear a high collar of rings of iron superimposed one above another; the forearms and the legs, for several inches above the ankle, are covered with similar rings.

When in fighting dress, the men wear an arrangement of feathers in a ring surrounding the face, a skin, generally of the Colobos monkey, fastened round the neck and hanging down the back, and strips of Colobos hide round the ankles and surrounding the leg just below the knee.

The chief weapons are spears, swords and shields. The spear is a characteristic shape, and meant only for use at close quarters; the blade is of the shape of a double-edged, straight sword, and is of great length; the shaft, of wood, is merely long enough to afford a grip ; the blade is balanced by a long pointed, cylindrical piece of iron as a pommel.

The swords are usually short; they are of a spatulate shape and double-edged. The grip is wound round with a strip of hide. The scabbard is of wood covered with hide.

The shield is large, oval, and convex in front. It is painted in red and white clay pigments. The devices used are various.

Bows and arrows are not unknown, but are not used in action, being mostly confined to the old mon.

Barter.-Brass and wire, especially iron wire, are in demand. Beads and cloth are also taken in exchange for native products.

\section{Karamojo.}

The men are almost nearly all well over medium height. Many attain a height of 6 feet 2 inches, and several individuals of the height of 6 feet 4 inches or 5 inches were observed.

The physical development is, as a rule, magnificent. The only peculiarity in build is that the clavicle is often short, so that an appearance of narrowness is given to the shoulders.

They are active, and run with exceptionally good action.

The women are of medium height. The prognathous type is very rare; the features are generally well developed.

The tribe has a great reputation as warriors.

Mode of Subsistence.-Chiefly by agricultural pursuits, they have also large herds of cattle, sheep, goats and donkeys.

The chief crop cultivated is millet. 
Agricultural implements consist of hoes, either with a long or short shaft.

The millet is cooked either by parching the grain or by heating a mass of millet flour with water.

The huts are small and round, with wattle walls and conical thatched roofs. The furniture consists of small wooden stools, also used as pillows at night.

Religion.-An indefinite belief in a Supreme Being and in the ghosts of ancestors appears to constitute their faith. The Supreme Being is known as "Akuja," and is invoked to protect the crops and for success in war.

Dead bodies seem, as a rule, to be merely deposited outside the villages to be eaten by hyenas, etc. The bodies of chiefs are, however, buried.

Marriage is not a matter of barter as amongst most tribes. The girl can veto the arrangements, and hence is regularly courted, her parents not interfering in any way until her wishes are known.

If a wife misconducts herself three times she may be returned to her lather's house, the latter returning to her husband the present originally received. There is no limit to the number of wives.

There are strict rules regarding disputes, which, if serious, are adjudicated on by a council of chiefs. Homicide is severely repressed. Murder is punished with leath. Accidental homicide may be pardoned the first time, but a second case is punished with death.

In war two fighting leaders are selected by the council of chiefs, and under these leaders are the various communities each under its own local chief as his representative. The division of spoil is carefully regulated.

When a child is born it is given blood as well as milk. If it develops milk teeth on the left side before the right, it is a bad omen, and a goat is sacrificed; but the child is not put to death as amongst some other tribes. The child receives a name which, in the case of a boy, is altered when he has been on the war-path. There is no fixed rule against a young man marrying before he has killed an enemy or been on the war-path, but as this is a warlike tribe and the women are allowed a voice in matrimonial arrangements, it is more or less a custom that a young man must distinguish himself in war before marrying.

They believe in omens, and before a raiding expedition consult the entrails of a goat.

They also believe in "medicine" for production of rain and to ward off" locusts. In the former case a black ox is killed and its blood caught and mixed with water in an earthen pot; a firc is then lighted and extinguished with the blood and water. Rain is supposed to follow if there has been no irregularity in the ceremony.

To ward off locusts a red-headed goat is selected and killed by a blow on the head; its stomach is then taken out and cust in the direction from which the locusts are coming; this is supposed to turn them.

A solemn oath is taken in the following way: A black ox is selected and speared, the interested parties then lake hold of a leg each, and these are cut 
from the body; each then partakes of the marrow from the leg he has thus received.

Arts and Manufactures.-A rude kind of black earthenware pottery is made.

Tobacco is smoked; the pipe in common use is fitted with a gourd, which is filled with water, through which the smoke is drawn.

The only intoxicating liquor is a fermented drink made from millet.

Iron is the only metal worked ; their weapons and implements are well made.

Personal Adornments, etc.-Marking by raised cicatrices is practically universal. Ear ornaments consist of a number of small rings, passed through the free edge of the ear. The lower lip is usually pierced, and a small piece of wood, ivory or brass wire inserted.

A characteristic ormament worn by men of importance is a collar formed of rings of iron lying one above another, and kept in position by vertical stays of the same metal. The arms are generally decorated with large bracelets of ivory.

The headgear of the men consists of a large mat of hair worn on the back of the head, and secured by a string passing round the forehead. This is supposed to be made from the hair of the wearer's ancestors. The men go about absolutely naked-the women wear small skins.

Circumcision is not practised.

The women wear necklaces of imported beads, and also made of small circular pieces of ostrich egg-shells, and of the vertebræe of snakes, with the ribs removed.

Weapons consist of spears and shields. The spears are formed for either thrusting or throwing; the heads are small, and of a bay-leaf shape; the neck of the blade is long and forms a considerable portion of the shaft. The edge of the blade is kept very shar p, and is protected by a rim of hide. The shields are very small, of an oblong shape, with concave lateral edges. The ivory bracelets worn on the forearm are very long, and are apparently so made as a means of protection. Knobkerries are also used, both for striking and throwing.

Many warriors also wear a circular iron bracelet, with a sharp cutting edge, for fighting at close quarters; the edge of this is, like the spear-liend, protected by a leather rim, which can be sprung off at once; to prevent this iron disc cutting the wrist, it is set into a leather bracelet, which protects the skin.

The expedition was a long time in the country of Karamojo, and our relations with this people were most friendly throughout. This was much facilitated by the fact that they had a tradition that white men would ultinately come to rule the country. As we were the first white men to enter Karamojo, the natives said the tradition had been fulfilled, and that the country was ours.

The Karamojo were a singularly honest people, the must honcst savages I had ever met. We bought large quantities of food from them, some 400 sacks of grain, the rate of exchange being one goat for a sack of millet. They always expected to be paid in advance, and on stating how many sacks they were prepared to provide, took away that number of goats and enpty bags. In one, 
two, or three days according to the distance of their homes from camp, they returned with the grain, and in no single case were they dishonest. On another occasion we paid a man seven goats to guide us for a month. After three days, however, he said he did not know the road we proposed taking and would rescind the contract. With this intimation he disappeared, and it was not until many a month later that we got back to our standing camp at Titi, when I found, somewhat to my surprise, I admit, that the absconding guide had returned the seven goats to the European in charge of the camp.

They have a very practical way of encouraging industry in the young. A child gets a smaller ration than an adult. But when the child grows up, and complains that the reduced ration is no longer sufficient it is presented with a hoe and told to assist in the common cultivation, if it expects an adult's fare.

The Suk-Nandi group are mountaineers and dwellers in forest regions. They have this in common that they do not live in villages, but in scattered hamlets of one or two houses, each with its own small patch of cultivation which produces little more than is necessary for the inhabitants. These patches of cultivation are, however, often irrigated with some skill. The natives are not, however, dependent on agriculture alone, as they have considerable flocks of goats and sheep and some cattle. Fowls are also kept, which is not the case amongst the Masai and kindred tribes. Amongst the Suk group of tribes both sexes are of medium height and slightly built. They are, however, active. The features are generally good, and only amongst the Suk and Anderobo does slight prognathism exist.

The tribal organisation is more poorly developed than amongst the surrounding tribes, and the power of combination seems small except perhaps amongst the Nandi and Suk.

The weapons used are bows with poisoned arrows, spears and shields. The members of this group are treacherous and unreliable with a few exceptions. They appear to have a vague belief in a Supreme Being, but very little is known of their religion.

Skins are cured, rude earthenware made, a fermented drink is prepared from millet, and iron is worked in the various districts, except Save, where iron implements are imported.

Except among the Suk, no disfigurement except ear-piercing is practised. fiar ornaments, generally of iron or brass, are worn in a perforation of the lobule. The males are naked; the females wear a short petticoat. The form of headdress is various. The Suk use the felted hair bag of Karamojo, while the Nancli, lakio and Save affect the Masai style.

A more detailed description of the Suk is given below:-The men are of melium height; the women are short in stature. Slight prognathism is common. Muscular development is fair.

Mote of S'llbsistence.-Those who dwell in the hills live by agriculture: 
irrigation is employed. Those who live in the plains, in the east of the Suk country are pastoral. Game is caught, chiefly by loop snares attached to heavy logs. The millet, which is the principal grain cultivated, is made into a coarse meal and cooked as a stiff porridge.

The huts are circular in plan, the walls made of upright poles plastered with mud, and the roofs, which are dome-shaped, are thatched. The houses are scattered and are not stockaded.

Iron hoes are used for cultivating.

Religion and Customs.-The Suk believe in a Supreme Being called "Akisomlorot," and have some idea of a future state. They pray for success in war. They do not appear to believe in rain or locust doctors.

A young man may marry before he goes on the war-path. He presents the parents of the girl he wishes to marry with a sheep. If they accept this, and thus signify that they agree, he returns in two days with a present of cattle and takes the girl away. If she objects, he waits and catches her outside the house and takes her to his hut. This relic of marriage by capture was also noticeable amongst the Save, where, however, the bridegroom may be assisted in the pursuit of the girl by a party of his friends.

On reaching the bridegroon's hut, the bride refuses to enter until the child of a neighbour is produced. With this in her arms she enters the bridegroom's house. There is no further ceremony.

If, as a wife, she misconducts herself she is sent back to her parents, who refund her price in cattle.

A woman with child is dieted. The child is named by the mother four days after birth. If a boy, he retains this name until his return from his first warpath, when his name is changed. If milk teeth first appear on the left side, it is a bad omen, and the child is not suckled, but fed on goat's milk. The child is weaned after three months.

The dead are carried into the bush. Even the body of a chief is left unburied, but an ox is slaughtered by the body, and the flesh of the ox may not be caten by any one.

The Suk, like the Nandi, appear to be capable of acting in bodies in war, and select two fighting chiefs. There are no elaborate preparations before starting on the war-path, although the warriors are supposed to eat as much meat as possible before taking the field. Ostrich feathers in their hair are a sign that they are on the war-path.

Their arrangements for dividing the spoil would also appear primitive. The two chiefs take their share and the balance is divided anyhow. In the adjustment of the inevitable disputes that arise, the use of spears is not allowed, but sticks and knobkerries may be employed.

If one Suk in peace time kill another, he is fined all his cattle, but is not put to death; if he only maims he has to pay ten cattle. Thioves are punished by being beaten with sticks. 
Disputants generally exchange spears as a sort of oath that they will abide by the settlement arrived at.

Arts and Manufactures.-Skins are cured, but not made into leather. A rude kind of earthenware is made. Millet is grown and the fields are often irrigated by small channels.

Tobacco is grown, and used as snuff. A fermented liquor is made from millet, and largely consumed. Iron is worked.

Personal Ornaments, Disfigurements, cte.-Some of the men are marked with patterns in raised cicatrices on the chest. The two central lower incisors are removed. Ear-rings of wire are worn by the men in the lobule, and a few also wear a ring in the septum of the nose. The lower lip is always perforated in the male sex; in this perforation is worn a pendint wire ornament from 4 to 6 inches in length. The hair of the men is commonly plastered with mud on the top of the head, and ornamented with feathers. Men of importance wear the long hair bag (shoalip) of the Karamojo. In either case a piece of wire is inserted into the hair posteriorly, and curved forward over the top of the head. The women wear their hair in the natural state. The men are generally naked except for the skin of a goat or monkey depending down the back. The women wear two or threc goat skins fastened round the waist. Circumcision is not practised.

Their weapons are spears, shields, bows and arrows. The spears are used either for throwing or stabbing. The blades are small, and of a bay leaf shape; the butt end is protected by a small sharpened pommel and the edge of the blade is protected, when not in use, by a rim of hide.

The shields are of wicker-work, and are oblong in shape, averaging about 3 feet in length, and 9 inches in breadth. The bows are well made, and the arrows have generally detachable thin wooden points which are poisoned and break off in the wound. A curved finger knife projecting, like a claw, from the finger ring, is also sometimes worn.

The members of the Bantu and Negro groups have been so fully described by others that it is unnecessary to deal with them in detail here, and I will conclude this paper with a few notes on the history of the tribes as gathered from their own legends and traditions.

\section{(c.) Notes on tile History of Certain Tribes as Regards Tieir Present and Past Geograpinical Distribution.}

This is a somewhat difficult matter as the data with which we have to work are very meagre, and it is not improbable that some of the deductions to which I have coine may be challenged or modified by others. But in dealing with such primitive peoples, it is very difficult to obtain any traditions as to their origin or migration, and I shall confine myself to the expansion, contraction and movements of the tribes concerned within the area considered, and leave the larger question of their actual origin to experts. 
Dealing first with the Eloegop, we find a tradition that they came from the country east of Lake Rudolf. Extending southward they conquered the whole of the grass lands adjacent to the meridional rift, enslaved the Anderobo there, occupied the plateau of Lykipia and nearly exterminated the "Senguer," who dwelt on the Guash Ngishu plateau.

As " 1 " and " $r$ " are interchangeable "Senguer" of the Juba expedition is evidently the same word as "Jangwel," a term which Mr. C. Hobley found was applied by the Nandi to designate their tribe. Still spreading onward the Eloegop occupied the grass lands far to the south, as far as, or even beyond, Mount Kilimanjaro. They then divided into three tribes, similar in language and custnms, but with a certain internal jealousy gradually growing into open war. The Sambur retained the country east of Lake Rudolf, the plateau of Lykipia and the meridional rift as far south as Baringt. The Guash Ngishu branch occupied the equatorial portion of the meridional rift and the grass plateaux on the Guash Ngishu and Mau; the Masai extended from Naivasha to Kilimanjaro. Civil war broke out between the Masai and Guash Ngishu who were helped by their kinsmen of Lykipia. After some initial defeats, the Masai detached the Sambur of Lykipia from the hostile alliance and then crushed the Guash Ngishu so utterly that the latter could no longer hold their own against the dispossessed Nandi and their kindred, and ceased to exist as a tribe. They are now scattered dwellers in Nandi, Kavirondo or Ketosh.

The Sambur weakened by the civil war were attacked by the Suk who lived on the southern portion of the Karamojo plateau, and were being expelled from their country by an advancing Karamojo wave. Under the pressure of the Karamojo the Suk migrated west and conquered from the enfeebled Sambur that portion of the meridional rift north of Lake Baringo, thus practically cutting off the Sambur of Njemps from those of Lake Rudolf. The latter had apparently to deal with the growing power of the Rendile, who show close affinities in language and customs with the Sornali, and the isolated Sambur of Njemps were shorn of their power under the attacks of two small villages near the south of Lake Baringo. The Sambur of Lykipia, weakened by war and isolation and impoverished by cattle plague, were in turn subject to attacks by the Rendile, and are now almost, if not quite, destroyed. Thus the once great dominion of the Eloegop is now represented by the southern branch, the Masai, and these, who suffered very much by their civil wars, the cattle plague and from small-pox, are perceptibly weakening in power, and signs are not wanting that a further split is in course of formation between the northern and southern Masai which will still further weaken this once powerful and much dreaded tribe.

In this sketch of the Eloegop, based on their own traditions, I have not referred to Latuka, as I could gather nothing to show any trace of the migration which separated these peoples, although their common origin would appear to be beyond a rloubt.

But in tracing the migration, southwarl, of the Eloegop, their great dominion 
and their gradual decay, we have incidentally arrived at certain evidence as to the relative antiquity within the geographical area considered, of certain other tribes. The Anderobo, Nandi and Suk must have been anterior to the advent of the Eloegop, while the Karamojo migration southward would appear of more recen $i$ date.

Passing on to the Suk-Nandi group, we find that they comprise amongst their members the Anderobo, and the Nandi (Sanguer or Jangwel) who were admittedly prior to the Eloegop, and also find that this group of tribes embraces many others who are now for the most part dwellers in the mountainous and forest regions in this part of Africa. These tribes, often small and insignificant in themselves, would appear to be broken fragments of a powerful and widespreading people who occupied an extensive trait prior to the advent of the Eloegop, Karamojo and Bantu conquerors.

It is also interesting to note that this group of tribes shows more connection in language with the Ogaden Somalis than do the tribes which now occupy the great expanse of intervening country. This is still more remarkable when we bear in mind that the northern Somalis rather look down on the Ogadens as having been more contaminated by mixture of blood with the aboriginal inhabitants.

The greater antiquity of the Suk-Nandi group as compared with the Eloegop is clear, and the Suk traditions, that they were dispossessed by the advance of the Karamojo, subsequent to the migration of the Masai, would appear evidence that the Karamojo wave is of still more recent date. There is also confirmation of the Suk claim to have formerly occupied the south of the Karamojo plateau, in the fact that the inhabitants of the Chemorongi mountains, which run as a wedge into the Karamojo and Turkana country, are Suk, and that small completely isolated colonies of Suk still dwell on the lofty mountains of Dehasien, Moroto and Kamalinga, in South Karamojo. The people of Save, who belong to the Suk-Nandi group, also say that they formerly occupied the plains north and east of Elgon until dispossessed by the Eloegop and Karamojo. The southward movement of the Karamojo would appear to have been at a much later date than that of the Eloegop, although the connection of their language and customs point to a common origin. The Karamojo themselves appear unknown to the Masai, but their kindred the Turkana are called the Elgumi.

The Karamojo, Turkana and Donyiro are branches of one tribe, of the same blood, language and customs, who have gradually moved southward and westward. The Elgumi west of Mount Elgon appear to be an offshoot of the Karamojo, and it is interesting to find that Mr. Hobley has discovered that only some 50-60 years ago these Elgumi threw off a colony which intruded into the Bantu people of Kavirondo and formed a settlement at Kikelelwa. This, coupled with the southern advance within the same period of the Karamojo on the east of Mount Elgon, would appear to show that the vitality of this great and warlike tribe is not yet exhausted. The Karamojo would also appear to have reached the Victoria Nile,

New Series, Vol. II, Nos. 3 a d 4. 
but the so-called Wakedi there are not pure Karamojo. It is more likely that while the Karamojo have conquered widely it is only on suitable country like the open grass plains that they retain their full characteristics, and in an unsuitable locality, they deteriorate through admixture with the conquered tribes better adapted than themselves to the local climatic conditions.

So far there has been little difficulty in establishing the opinion that the SukNandi were prior to the Eloegop and the latter to the Karamojo, but in ascertaining the comparative antiquity of the Bantu and Negro tribes there is much less to go on. The Bantu people of North Kavirondo, however, state that they came from the south, while the people of Masawa (and Ketosh) are said to have migrated by way of Usoga. The fact that the former are mainly growers of grain and potatoes, while the Masawa people resemble the Wasoga and Waganda in largely cultivating bananas, would appear to support this tradition. The Nyifa or South Kavirondo, a tribe allied to the Negro Shuli, have no tradition as to their origin, and no knowledge of their cousins in the north. This fact might be taken to indicate that their presence in Kavirondo is prior to the Bantu. The Bantu Kavirondo have moreover secured the best part of the country, viz., that with two rainy seasons, while the Negro Kavirondo are confined to that portion with only one rainy season. This would all point to the Bantu Kavirondo being the more recent conquerors in the country. I am also led to believe that the Negro Nyifa in Kavirondo are anterior to the Masawa, and that the Jigumi are of still more recent origin.

The Masawa people have always spoken of the latter as encroachers, if not interlopers, and the Kikelelwa incident shows a spreading tribe.

If the Negro Kavirondo reached their present position from Shuli country by the East of the Nile and Victoria, it would appear probable that they were isolated by the intervening country between Mount Elgon and the Nile being occupied by the Bantu, who were themselves more recently sub-divided by an intrusive wedge of Elgumi, who separated Masawa from Usoga.

It is interesting to note that the Wasoga, Waganda and Wanyoro know the Elgumi and Lango as Bakedi, or the naked people, while the equally naked shuli are called by a distinctive name Bagani, and the Kavirondo are called Bakavirondo. Now it is hardly likely that the epithet "naked people" would be applied to a neighbouring tribe unless those who applied the term had some clothing themselves, and there is reason to believe that the Bantu peoples in the Victoria region have gradually developed a taste for clothing and were originally as naked as any one else there. The Waganda admit to the Bakedi raiding across the Nile, and to many more or less unsuccessful counter raids, but I have never heard them claim to have dispossessed the Bakedi of territory. On the other hand the fact that the Shuli have a specific name Bagani applied to them, not unlike the Bantu word for aliens, would show that the Bantu people knew them as a distinct tribe, and would tend to indicate that the Bakedi appeared later in the field. More reliable data as to this point should, however, be procured in Uganda, and doubtless 
will be forthconing, if others will, like Mr. C. Hobley, take an interest in such investigations. But as matters stand, I would favour the theory that the Negros preceded the Bantu, and the Bantu preceded the Elgumi, Lango and Karamojo. Thus if we consider the more limited area in which there mingle representatives of the Negro, Bantu, Suk-Nandi, Masai and Karamojo I am led to conclude that the Karamojo are the most recent arrivals. Before them was a wave of Bantu sweeping northwards and of Masai (Eloegop) sweeping southwards dispossessing and encronching on the older inhabitants represented by the Negros and SukNandi families. Whether the Bantu or Eloegop were earlier in the field is uncertain, but it is noteworthy that the Masai were known to the Waganda, who had a prophecy, strangely brought to pass by the British occupation of Uganda, that their country would be conquered through Masailand. The relative antiquity of the Negro tribes and the Suk-Nandi in their present geographical position is uncertain, and there is nothing on which to base an opinion, but on this point, too, further research may throw some light.

The whole question is a difficult one, but some of my conclusions appear to rest on a fairly solid foundation. In other cases, there may not be sufficient grounds to establish my theory, but as I have given my reasoning I trust that, even should the conclusions be afterwards proved inaccurate, in certain details, the work of my recent expedition has at all events thrown a little additional light on the most interesting problem of the ethnology of these regions.

\section{Discussion.}

Mr. CROOKE remarked that for him this paper possessed special interest because in it a mass of materials was collected which would be of value in considering the Negrito element in the Indian population, which probably reached the Peninsula from the opposite Continent of Africa. Some of the customs described by Lt.-Col. Macdonald were from this point of view of special interest. Thus, the wearing by the bridegroom of his bride's petticoat for some time after marriage suggested similar customs of sex disguisenent in India, of which rarious explanations might be formulated. The Masai custom of bush burial in the case of lower class people might be compared with similar Indian burial rites as described in a paper contributed by him to the present number of the Journal. The question of female circumcision among the Somalis was discussed by Major J. S. King, in Vol. II, Journal Anthropological Society of Bombay. So far it does not appear to have been traced in India. The blood covenant oath of the Karamojos is an interesting parallel to similar Arabian rites, as described by Dr. Robertson Smith. The Suks appear to have a well-developed custom of bride capture. The bride takes a child in her arms probably as a fertility charm.

Mr. Shrubsalu pointed out the manner in which the lantern slides just exhibited illustrated the probable physical as opposed to the linguistic or social unity of the negro races of Africa, drawing attention to certain features of resemblance between the natives of the country to the north-easi of the great lakes, and those depicted on the Benin castings now at the British Museum. 
CENTRAL AFIICAN

Collected by Lieut.-Colonel J. R. L. Macdonald

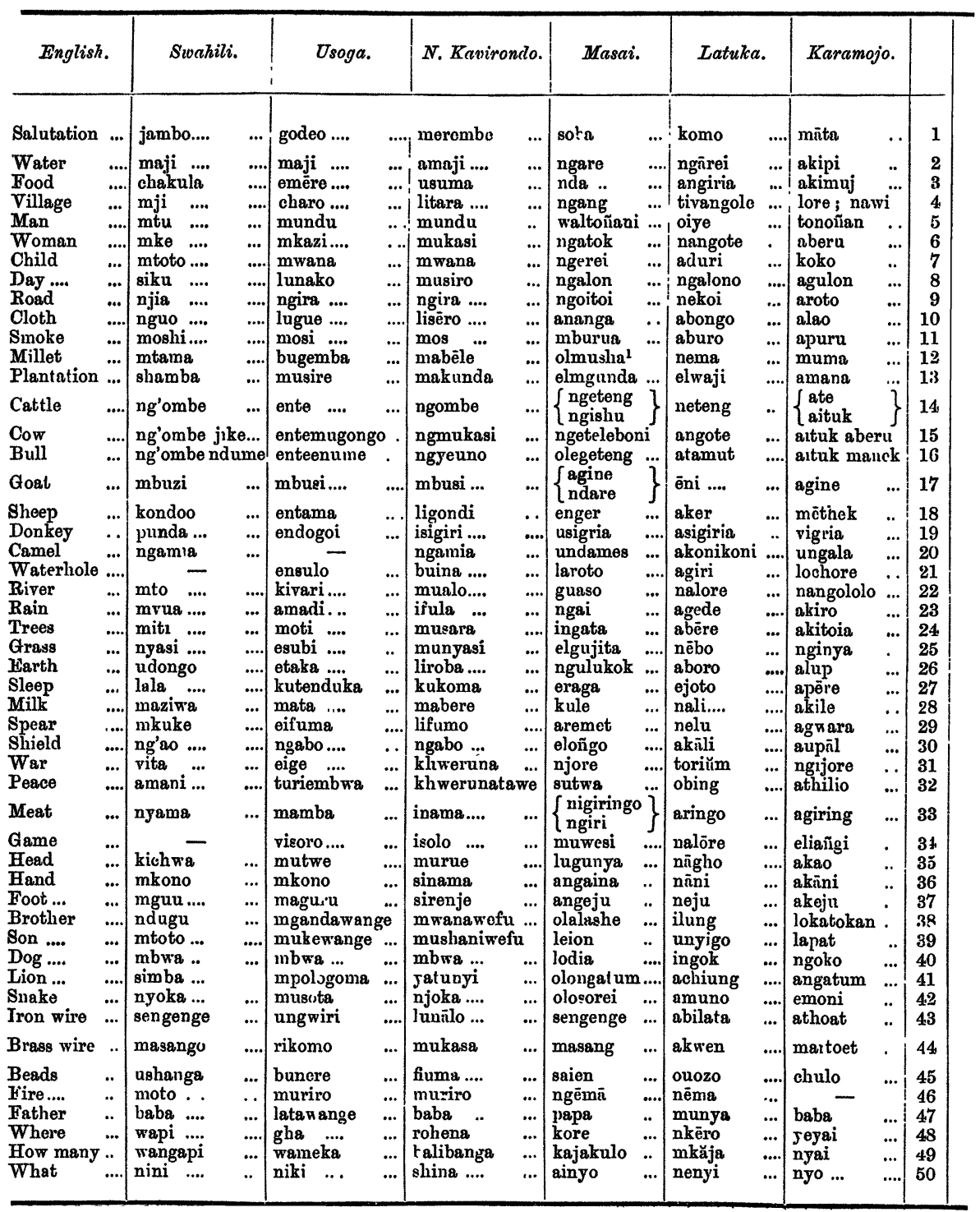

l Kikuyu word. 


\section{VOCABULARIES.}

IN THE COURSE OF THE JUBA EXPEDITION.

\begin{tabular}{|c|c|c|c|c|c|c|c|c|c|c|c|c|c|}
\hline & \multicolumn{2}{|l|}{ Suk. } & \multicolumn{2}{|l|}{ Nandi. } & \multicolumn{2}{|c|}{ Wanderobo. } & \multicolumn{2}{|l|}{ Save. } & \multicolumn{2}{|c|}{$\begin{array}{l}\text { S. Kavirondo } \\
\text { Wanyifa. }\end{array}$} & \multicolumn{2}{|l|}{$\begin{array}{l}\text { Borana } \\
\text { Galla. }\end{array}$} & $\begin{array}{l}\text { Ogaden } \\
\text { Somali. }\end{array}$ \\
\hline 1 & chamkechs & & chamke & $\cdots$ & sobei & $\cdots$ & sobei .... & $\cdots$ & mosi .... & & $\begin{array}{l}\text { nagaya } \\
\text { kabla. }\end{array}$ & & $\left\{\begin{array}{l}\text { mot. } \\
\text { manwadba. }\end{array}\right.$ \\
\hline 2 & pau & ... & pēk .... & .... & pēk .... & .... & piko .... & .... & pi $\quad \ldots$. & .... & bishan & ... & biā. \\
\hline 3 & ama & $\ldots$ & amit & .... & amit & $\ldots$ & ngumia & .... & kōni .... & .... & sagăle & ... & sōrta. \\
\hline 4 & ngokatany & & keita & .... & kaita & .... & kota .... & .... & pācho.... & $\ldots$ & karang & $\ldots$ & băıăda. \\
\hline 5 & akōgo & $\ldots$ & pik .... & .... & kiito & .... & moran & $\ldots$. & thano .... & $\ldots$ & sifeda & $\ldots$ & āděgā. \\
\hline 6 & korkoni & $\ldots$ & korke & .... & korko & .... & koroko & .... & thako .... & $\ldots$ & intala & .... & nākta. \\
\hline 7 & mōnū & $\ldots$ & lakwe & .... & lagwe & ... & lekwa.... & ... & nyathi & .... & jōle.... & .... & elmā. \\
\hline 8 & akogo & .... & petunok & .... & āeng & $\cdots$ & sisita .... & $\cdots$. & ndal .... & ... & guyan & $\ldots$ & āwa. \\
\hline 9 & ore .... & .... & orana & $\cdots$. & ōre .... & $\cdots \cdot$ & areti .... & $\cdots$ & wangio & $\cdots$ & tirbū & $\cdots$ & wadada. \\
\hline 10 & alao & .... & ange & $\cdots$. & ange & $\cdots$ & $\begin{array}{l}\text { kirenget } \\
\text { ingitim }\end{array}$ & $\ldots$. & lao $\quad \ldots$. & $\cdots$ & $\begin{array}{l}\text { wāya } \\
\bar{a} r\end{array}$ & $\cdots \cdot$ & marada. \\
\hline $\begin{array}{l}11 \\
12\end{array}$ & $\begin{array}{l}\text { âros } \\
\text { mosong }\end{array}$ & $\cdots$. & $\begin{array}{l}\text { iyet.... } \\
\text { mosangik }\end{array}$ & $\cdots .$. & $\begin{array}{l}\text { aros } \\
\text { mosong }\end{array}$ & $\cdots$. & $\begin{array}{l}\text { ingitim } \\
\text { musongek }\end{array}$ & $\begin{array}{l}\ldots \\
\ldots\end{array}$ & $\begin{array}{ll}\text { iro } & \ldots . \\
\text { bēl } & \ldots . .\end{array}$ & $\ldots$ & $\begin{array}{l}\text { är .... } \\
\text { machabo }\end{array}$ & $\cdots$. & $\begin{array}{l}\text { kēka. } \\
\text { harurk. }\end{array}$ \\
\hline 13 & matei & $\cdots$ & pēk.... & $\cdots \cdot$ & pēk.... & $\cdots$ & imperet & $\cdots$ & puotho & $\cdots$ & öru .... & $\cdots$ & bërta. \\
\hline 14 & taiñge & ... & tōgha & .... & tōka & .... & teta & $\ldots$ & viang .... & $\ldots$ & lawōni & $\ldots$ & löta. \\
\hline $\begin{array}{l}15 \\
16\end{array}$ & $\begin{array}{l}\text { sakāt } \\
\text { yeāi }\end{array}$ & … & $\begin{array}{l}\text { iwoge } \\
\text { aito.... }\end{array}$ & $\begin{array}{l}\ldots . \\
\ldots . .\end{array}$ & $\begin{array}{l}\text { sakāt } \\
\text { etto .... }\end{array}$ & $\begin{array}{l}\cdots \\
\cdots .\end{array}$ & $\begin{array}{l}\text { teta koroko } \\
\text { tēta moran }\end{array}$ & $\cdots$. & $\begin{array}{l}\text { riangmathak } \\
\text { ruath .... }\end{array}$ & $\begin{array}{l}\text { ko } \\
\ldots . . .\end{array}$ & $\begin{array}{l}\text { kōrămsa } \\
\text { kibīch }\end{array}$ & $\cdots$ & $\begin{array}{l}\text { sadidik. } \\
\text { dibika. }\end{array}$ \\
\hline 17 & ngoror & .... & nioko & .... & arte .... & $\ldots$ & warēk.... & .... & dieli .... & $\ldots$ & khrēē & .... & arega. \\
\hline 18 & kēsh & .... & kicherek & .... & kēchē & .... & mangit & .... & rombo & $\ldots$ & khōlā & $\ldots$ & edā. \\
\hline 19 & sigria & $\ldots$. & sigire & .... & sigria & .... & sigria ... & .... & kanyema & $\ldots$ & ărē .... & $\ldots$ & tomēra. \\
\hline 20 & tāmās & .... & tamesi & .... & tombes & .... & tembes. & .... & aluo ,.... & $\ldots$ & gāl .... & .... & gel. \\
\hline 21 & pau.... & .... & kererkie & .... & luge & .... & pikopañoi & .... & awachi & .... & kōno & ... & lechan. \\
\hline 22 & ền $\ldots .$. & .... & endo & .... & èn .... & $\ldots$ & eitoni .... & .... & āora .... & $\ldots$ & endata & .... & durdurka. \\
\hline 23 & rōp .... & .... & torōt & .... & rōpta & .... & ropta .... & .... & koth .... & .... & bøkēè & .. & rōp. \\
\hline 24 & kuendo & $\ldots$. & ketit & .... & ketit & $\ldots$ & katet .... & .... & yath .... & $\ldots$ & mūku & ... & huiyet. \\
\hline 25 & susōm & .... & susuandi & .... & susuon & .... & suswek. & .... & lum .... & ... & būyo & ... & āūsk̆. \\
\hline 26 & numoi & ... & numunyēk & ..... & nongum & .... & kitopañoi & .... & lō $\ldots . .$. & .... & biye & .... & āro. \\
\hline 27 & rūēè .... & $\ldots$ & kaguruiyo & .... & mauru & $\ldots$ & ruondo & .... & anēndo & .... & räfi .... & ... & sāhao. \\
\hline 28 & keko & $\ldots$. & kiyeko & .... & keiko & .... & kiko .... & .... & chaki .... & .... & ānăn & .... & āna. \\
\hline 29 & ngōt & $\ldots .$. & añgotet & .... & ngotit & .... & akwar.... & $\ldots$ & tong $\ldots$. & $\ldots$ & warān & .... & warākă. \\
\hline 30 & longē & .... & long & .... & longe & .... & loñget.... & .... & kuot .... & .... & wantē . & .... & kāshān. \\
\hline 31 & lūk .... & $\ldots$ & lūke & .... & setluge & .... & parare & $\ldots$ & lueni ... & .... & nyābiadufe & & těreřta. \\
\hline 32 & mis .... & … & tiliye & .... & tilia & .... & kutai .... & $\cdots$ & merembe & .... & nagējira. & .... & nabăt. \\
\hline 33 & pēng & .... & penda & $\ldots$ & pănyek & $\cdots$ & pendo.... & .... & ringo .... & ... & fōn .... & .... & hřlip. \\
\hline 34 & arawa & .... & arawe & .... & arāwe & .... & makao & .... & $l \bar{e}, \ldots$ & .... & - & & - \\
\hline 35 & mēt.... & .... & metit & .... & metit & .... & metit .... & ... & wich .... & .... & matā & .... & madaha. \\
\hline 36 & èyi .... & .... & èyu.... & .... & 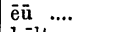 & $\ldots$ & - - & & luedo .... & $\ldots$ & hărkă & .... & kānta. \\
\hline 37 & kēl .... & $\ldots$. & keldo & .... & kēlto & $\ldots$ & kirenget & .... & tielo .... & .... & lūkū & $\ldots$ & lugha. \\
\hline 38 & wurtanyo & $\ldots$ & keturche & .... & ellte.... & $\ldots$ & tjliangani & .... & wadwa & ... & ōbōles & $\ldots$ & wâlala. \\
\hline 39 & nyēta & .... & nyētik & .... & lakwe & .... & kwero.... & .... & omēra & $\ldots$ & mūchā & ... & arorta. \\
\hline 40 & kugwi & $\ldots$ & sềsē.... & .... & chugui & $\ldots$ & ngoniti & .... & guōk .... & .... & săve & .... & \\
\hline 41 & kawai & $\ldots$ & abiye & ... & kiesing & $\ldots$ & - & & siburi.... & $\ldots$ & nēk .... & .... & libēha. \\
\hline 42 & moroi & .... & ērēn & .... & ērēn & $\ldots$ & njoki .... & $\ldots$. & tuōl $\ldots$. & $\ldots$ & băfu & .... & măsk. \\
\hline 43 & titir & .... & tobokwe & .... & tobokwe & .... & sengenge & $\cdots$ & malo .... & … & - & & \\
\hline 44 & tai .... & .... & tāe .... & $\cdots$. & tai $\ldots$. & $\cdots$. & $\left\{\begin{array}{l}\text { sengenge } \\
\text { amulum }\end{array}\right.$ & \} & mola .... & $\cdots$ & - & & mārta. \\
\hline 45 & sonei & $\cdots$ & soneiet & .... & sonoi & $\ldots$ & sonaia.... & .... & utiti .... & $\ldots$ & - & & kosha. \\
\hline 46 & māt.... & $\ldots$ & māstinock & $\ldots$ & māt.... & .... & - & & māch .... & $\ldots$ & ibită & .... & tābka. \\
\hline 47 & paponyan & $\ldots$ & paipai & $\ldots$ & pabwa & .... & . - & & urwa .... & $\ldots$ & abaki & .... & abahi. \\
\hline 48 & ngô.... & .... & ngiro & .... & ano.... & .... & miono.... & .... & akānye & .... & kulote & .... & $\bar{a} w \bar{e}$ \\
\hline 49 & adeng & ... & ata .... & $\ldots$ & ata .... & .... & ata $\ldots$. & .... & adi $\quad . .$. & .... & nagăm & ... & wamisa. \\
\hline 50 & kenya & $\ldots$ & kelene & .... & ne $\ldots$. & $\cdot$ & $\cdots$ & $\cdots$ & ango... & $\cdots$ & wansūm & ... & wamhei. \\
\hline
\end{tabular}


C'ENTRAL African

\begin{tabular}{|c|c|c|c|c|c|c|c|c|c|c|c|c|c|c|}
\hline Englush. & & Swahili. & & Usoga. & & N. Kavirond & & Masai. & & Latuka. & & Karamojo. & & \\
\hline To-day & $\ldots$ & leo $\quad \ldots$. & $\ldots$ & lero .... & ..... & sitere .... & & tata.... & .... & aghīna & $\ldots$ & takñi & .... & 51 \\
\hline Yesterday & $\ldots$. & jana .... & $\ldots$ & ido .. & $\ldots$ & shavere & $\ldots$. & ngole & $\ldots$. & ngolonole & $\ldots$ & beāli & .... & 52 \\
\hline In front & $\ldots$ & mbele.... & .... & mberi.... & $\ldots$ & mbiri .... & $\ldots$ & lugunya & $\ldots$. & agosiere & .... & kingaren & .... & 53 \\
\hline Behind & $\ldots$ & nyuma & $\ldots$ & enuma & $\ldots$ & munuma & $\ldots$. & kurum & $\ldots$ & negalo & $\ldots$. & kao.... & .... & 54 \\
\hline To-morrow & .... & kesho .... & .... & enjo .... & .. & machuri & .... & teiseri & .... & moite & .... & moi.... & $\cdots$ & 55 \\
\hline No .... & $\ldots$ & hakuna & .... & ira $\quad \ldots$ & .... & shishirio & .... & mēti & $\ldots$ & abeng & .... & mäm & .... & 56 \\
\hline All .... & ... & wote .... & .... & vuona.... & .... & vos ..... & .... & poege &.. & ingiye & .... & dādang & $\cdots$ & 57 \\
\hline After & .... & baada.... & .... & linda .... & . & basiri .... & .... & ngor & $\ldots$ & idigido & $\therefore$ & togwa & .... & 58 \\
\hline Now ... & $\ldots$ & sasa .... & .... & begano & $\ldots$ & bulano & ..... & tata.... & $\ldots$. & teniaghani & i.... & tete ... & $\ldots$ & 59 \\
\hline Here & .... & hapa .... & ... & ghano.... & .... & ano $\quad . .$. & ..... & ene .... & .... & teni ... & .... & nege & .... & 60 \\
\hline There & $\ldots$ & huko .... & $\ldots$. & eyo ..... & $\ldots$. & eria $\quad . .$. & .... & idlye & .... & dia ... & .... & ama & $\ldots$ & 61 \\
\hline Near & ... & karibu & .... & gambi.... & .... & nahambi & .... & $\tan a$ & $\ldots$ & egutu & $\ldots$. & api .... & .... & 62 \\
\hline Far .... & .. & mbali .... & $\ldots$ & aghala & $\ldots$. & nehale & .... & alagwa & .... & alamaja & .... & aluana & .... & 63 \\
\hline Who & $\ldots$ & nani $\ldots .$. & .... & nani .... & $\ldots$. & wina .... & .... & engai & $\ldots$ & ngaiye & $\ldots$ & ngai & $\ldots$. & 64 \\
\hline Whose & $\ldots$ & ya nani & . & chani ... & .... & shawina & $\ldots$ & kenengai & $\ldots$ & anangai & .... & kangai & $\ldots$ & 65 \\
\hline My .... & $\ldots$ & yangu .. & $\ldots$ & yange ... & $\ldots$ & yanje .... & $\ldots$ & enai & & ununa & .... & kang & .... & 66 \\
\hline Your & .... & yako .... & .... & iyo $\quad . .$. & .... & iyiyo .... & $\ldots$ & line.... & .... & onungana & $\ldots$ & koni & .... & 67 \\
\hline $\mathrm{His} . . .$. & .... & yake .... & .... & chono.... & $\ldots$. & nasisis & $\ldots$ & lanye & .... & onalia & .... & kalu & .... & 68 \\
\hline Bring & .... & leta .... & $\ldots$ & leta .... & .... & lera & ... & eao.... & $\ldots$ & eau .... & $\ldots$ & yao.... & .... & 69 \\
\hline Come & .... & njoo $\ldots .$. & .... & èda $\quad . .$. & .... & inza .... & $\ldots$ & wao.... & .... & uwang . & $\ldots$ & bwa & $\ldots$ & 70 \\
\hline Want & .... & taka .... & ... & nenda.... & .... & ninyere & $\ldots$ & aiyao & .... & yatakitani & iye & achamet & .... & 71 \\
\hline Go .... & $\ldots$ & nenda.... & .... & genda ... & $\ldots$ & kenda.... & $\ldots$ & shomol & $\ldots$ & ilo ... & $\ldots$ & toloto & $\ldots$ & 72 \\
\hline Will reach & $\ldots$ & tafika .... & $\ldots$ & tunatoka & $\ldots$ & kuola .... & $\ldots$ & tabeiye & $\ldots$ & abanya & $\ldots$ & abun & $\ldots$ & 73 \\
\hline Wait & .... & ngoja .... & ... & rinda .... & ..... & rinda .... & .... & tanyo & .... & ètřlanani & $\ldots$ & dareo & $\ldots$ & 74 \\
\hline Tell .... & .... & ambia ... & $\ldots$ & nkobera & .... & songiri & ... & tolimu & .... & ekiana & $\ldots$ & tolomokin & $\ldots$ & 75 \\
\hline $\mathrm{He}$ is comin & & anakuja & $\ldots$ & aida $\quad . .$. & $\ldots$ & aredza & .... & $a^{l}$ otu & $\ldots$ & atuade & $\ldots$ & aloto & $\ldots$. & 76 \\
\hline $\mathrm{He}$ is going & & anak wenda & . & agenze & $\ldots$ & akendire & .... & alle... & .... & ilo ... . & $\ldots$ & alothi & ... & 77 \\
\hline Call .... & ... & mwite ... & $\ldots$ & mwete & $\ldots$ & mulange & $\ldots$ & mboto & $\ldots$ & nităk & $\ldots$ & tanyara & $\ldots$ & 78 \\
\hline Do you kno & & wajua ... & $\ldots$ & indidi.... & $\ldots$ & manyire & $\ldots$. & ayolo & $\ldots$ & mejakene & $\ldots$ & iyen & $\ldots$ & 79 \\
\hline Finished & & mekwisha & $\ldots$ & bamaze & $\ldots$ & bauëre & $\ldots$ & edibe & $\ldots$ & atukoi & .... & armure & $\ldots$ & 80 \\
\hline Take away & $\ldots$ & chukua & $\ldots$. & situra ..... & $\ldots$ & kinga & .... & èwa ... & $\ldots$ & ebiam & $\ldots$ & toting & $\ldots$ & 81 \\
\hline Speak & $\ldots$ & sema .. & $\ldots$ & yogēra & ... & simga .... & ... & eroro & $\ldots$ & ekiana & $\ldots$ & tolomokin . & $\ldots$ & 82 \\
\hline Drink & .... & kunywa &.. & kunya & .... & ama .... & .... & aitangik & $\ldots$ & amata & $\ldots$ & amathe. & $\ldots$ & 83 \\
\hline Eat .... & .... & kula .... & .... & kuria .... & .... & dia $\quad . . .$. & .... & enāsa & $\ldots$ & ingiye & $\ldots$ & anāmi & $\ldots$ & 84 \\
\hline To fight & .... & ku pigana & $\ldots$ & burwana & $\ldots$ & kukweana & .... & matarata & .... & toriamu & $\ldots$ & iyare & $\cdots$ & 85 \\
\hline Make & .... & fanya .... & .... & kola .... & $\ldots$ & khola .... & $\ldots$ & enderoni & .... & egani & .. & - & & 86 \\
\hline Dear & .... & ghali .... & $\ldots$ & kikalanguf & $\ldots$ & kitinyere & .... & agu .... & .. & omutari & $\ldots$ & agugum & $\ldots$ & 87 \\
\hline Cheap & .... & rahisi.... & $\ldots$ & vioru .... & $\ldots$ & bulai .... & .... & kelelak & .... & niñaña & $\ldots$ & agilejok & $\ldots$ & 88 \\
\hline Fast.... & ... & upesi .... & .... & mangumangu & & chia .... & .... & tasiugu & $\ldots$ & kokwak & $\ldots$. & tomatūm & $\ldots$ & $\delta 9$ \\
\hline Slow & .... & polepole & $\ldots$ & mpola... & $\ldots$ & kala .... & .... & aketiaketi & $\ldots$ & $\operatorname{mimo}$ & .... & aditadit & $\ldots$ & 90 \\
\hline Unripe & .... & bichi .... & ... & kibisi .... & $\ldots$ & kivisi .... & $\ldots$ & keshala & $\ldots$ & obuji & .... & ajonok & $\ldots$ & 91 \\
\hline Good & .... & mzuri.... & ... & murungi & $\ldots$ & mulai .... & ..... & sederi & .... & yoghoma & $\ldots$ & ajokan & $\ldots$ & 92 \\
\hline Bad .... & .... & mbaya & ... & mubi .... & .... & momubi & .... & torono & .... & orogho & .... & orono & .... & 93 \\
\hline Red .... & .... & mwekundu & .... & mweru & .... & mulaf .... & .... & nanyuki & .... & odoiret & .... & narengan . & .... & 94 \\
\hline White & .... & mweupi & .... & lueru .... & ... & ndaf .... & .... & neibor & .... & olobong & .... & nakwañan & $\ldots$ & 95 \\
\hline Black & .... & mweusi & .... & mwidugavu & .... & nimumari & .... & narok & ... & lamole & .... & - & & 96 \\
\hline Blue & .... & $\begin{array}{c}\text { kama maji } \\
\text { bahari. }\end{array}$ & ya & luvuvu & .... & nimumari & .... & naivasha & .... & losura & .... & nakirionon. & a.... & 97 \\
\hline Brave & .... & hodari & $\ldots$ & mukalangufa & & muting & .. & chogul & .... & ogol & .... & - & & 98 \\
\hline One .... & .... & moja .... & .... & mulola & & mulala & .... & nabo & $\ldots$ & aboite & $\ldots$ & apei & $\ldots$ & 99 \\
\hline Two.... & .... & mbili .... & $\ldots$ & babili .... & $\ldots$. & mabili & .... & are... & ..... & arega & $\ldots$ & nyare & $\ldots$ & 100 \\
\hline Three & $\ldots$ & tatu .... & $\ldots .$. & basatu & $\ldots$ & mataro & .... & uui .... & $\ldots$ & kunugoe & $\ldots$ & nyaini & $\ldots$ & 101 \\
\hline Four & .... & nne $\quad . .$. & .... & bana .... & .... & bane .... & .... & oñon & .... & ongwan & .... & nyomon & $\ldots$ & 102 \\
\hline Five .. & .... & tano $\ldots$. & $\ldots$ & batano & $\ldots$ & barano & .... & miet & ... & miet &.. & akan & $\ldots$ & 103 \\
\hline $\operatorname{Six} \ldots$. & .... & sita $\quad \ldots$. & $\ldots$ & mkaga & .... & basaba & & ile .... & . & ile .... & .... & akankapei & .... & 104 \\
\hline Seven & .... & saba $\ldots$. & $\ldots$. & musamva & $\ldots$. & baranonababi & & nabishyan: & & ghatarăk & .... & akankare & $\ldots$ & 105 \\
\hline Eight & $\ldots$ & nane .... & .... & munana & .... & banana & $\ldots$ & ishiete & $\ldots$ & kotoguni & .... & akankaune & e.... & 106 \\
\hline Nine & $\ldots$ & tissa $\ldots$. & $\ldots$ & muenda & $\ldots$. & barananabane & & naūdo & $\ldots$ & kotongon & $\ldots$ & akankaomo & on & 107 \\
\hline Ten .... & $\ldots$ & kumi .... & $\ldots$ & ikumi.... & $\ldots$ & kekume & ... & tomon & & tomon & .... & tomon & $\ldots$ & 108 \\
\hline
\end{tabular}

1 rerb alle. 
VocabULARIES-continued.

\begin{tabular}{|c|c|c|c|c|c|c|c|c|c|c|c|c|c|}
\hline & Suk. & & Nandi. & & Wanderob & bo. & Save. & & $\begin{array}{l}\text { S. Kavirond } \\
\text { Wanyifa. }\end{array}$ & & $\begin{array}{l}\text { Borana } \\
\text { Galla. }\end{array}$ & & $\begin{array}{l}\text { Ogaden } \\
\text { Somali. }\end{array}$ \\
\hline 51 & iye .... & .... & nauoni & $\ldots$ & ngolēl & .... & laut .... & $\ldots$. & tinende & $\ldots$ & bōru & & măngta. \\
\hline 52 & oino & ... & amut & $\ldots$ & omut & $\ldots$ & amtum & $\ldots$ & nyoro .... & .... & bōrtirīm ? & ?... & shali. \\
\hline 53 & tai .... & .... & tai ... & ... & huimet & .... & - & & atelo .... & .... & dăbări & ... & hōrei. \\
\hline 54 & let .... & .... & letut & $\ldots$ & lēt .... & .... & siskina & $\ldots$ & kiēn .... & $\ldots$ & jēbe & .... & tibonoko. \\
\hline 55 & oinopet & .... & karou & $\cdots$ & ärōl.... & .... & tuni .... & $\ldots$ & king .... & $\ldots$ & bortirom? & $\ldots$ & biri. \\
\hline 56 & maminye & .... & matinye & .... & momi & $\cdots$ & purio .... & ... & onge .... & ... & imbeku & $\ldots$ & mñakăn. \\
\hline 57 & tukul & .... & tokol & $\ldots$ & togul & $\ldots$ & tukul .. & $\ldots$ & lundo.... & ... & wasuntutu & $a \ldots$ & kulugei. \\
\hline 58 & mulëgit & $\cdots$ & toma & $\ldots$ & marobon & $\cdots$ & tombo .. & $\ldots$ & podi .... & ... & endufine & .... & wali. \\
\hline 59 & ive .... & $\ldots$ & raune & $\ldots$ & ongolen & $\ldots$ & rīūt ... & ... & kauon ... & .... & wānsum & ... & ata. \\
\hline 60 & iyēte & $\cdots$ & yū $\ldots$ & $\ldots$ & ìyu.... & $\cdots$ & ule & .... & karkai & $\ldots .$. & ārma & .... & mēchăn. \\
\hline 61 & yuno & $\ldots$ & olim & $\ldots$ & iyun & $\ldots$. & inyi & $\ldots$ & kucha :: & .... & kulothi & .... & Jlāgo. \\
\hline 62 & lēg1t & $\ldots$ & legit & $\ldots$ & lēgit & .... & - & & machegine & .... & tai .... & .... & sedo. \\
\hline 63 & lōwet & $\ldots$ & $10 \quad \ldots$ & $\ldots$ & $10 \%$ ?.... & .... & - & & mabori & .... & bāyā & .... & hagafukla. \\
\hline 64 & ilat? & $\ldots$ & törot & $\cdots$ & ichingo & $\cdots$ & ñgo $\quad . .$. &... & ngawa.... & $\cdots$ & wansūn & .... & waijo. \\
\hline 65 & ong̈onyete & $\ldots$ & pongoki & $\cdots$ & pongo & $\ldots$. & pango ... & $\cdots$ & maruga? & ... & kaunuti & .... & äyale. \\
\hline 66 & nenyān & $\cdots$ & nanye & $\ldots$ & nenjune & .... & nauีพane & .. & mära .... & ... & kănkīya & .... & anale. \\
\hline 67 & กีañgu & . . & nangun & .... & nangun & $\ldots$ & nyanuni & ... & māri $\ldots$. & $\ldots$ & kanketi & $\therefore$ & sagale. \\
\hline 68 & pæuềi & $\ldots$ & mananjo & .... & roni.. & ... & nyangun & .... & marejalicha & ... & kahebeluti & & nikasale. \\
\hline 69 & ubune & .... & konu & .... & obun & .. & suturi ... & $\ldots$ & kēl $\quad \ldots$ & ... & kotim & .... & kēn. \\
\hline 70 & nyōna & ... & abwa & .... & ño $\ldots$. & ... & kujoli ... & $\ldots$ & $a b^{\overline{1}} \quad \ldots$ & .... & koi... & .... & kāle. \\
\hline 71 & amachan & ... & a!nache & $\ldots$ & amache & .. & kucham & .... & adwaro & .... & malefet & $\ldots$ & wandoni. \\
\hline 72 & kepecha & $\ldots$ & ui ... & ... & këbe & .. & kepichike & $\ldots$ & wathio & $\ldots$ & ējem & .... & sāu. \\
\hline 73 & njona & $\ldots$ & keitete & $\ldots$ & kaitete & .... & kuo ... & $\ldots$ & atundu & ... & b̆̈rర & $\ldots$ & wāgāri. \\
\hline 74 & kanja & $\ldots$ & kanyet & $\ldots$. & kanya & $\ldots$ & sis $\quad \ldots$. & .... & rit $\ldots$ & .... & ēch ... & $\ldots$ & juk. \\
\hline 75 & maūūne & $\ldots$ & maun & $\ldots$ & mōkin & $\ldots$ & kungala & $\ldots$ & wachima & ... & bobifeda & .... & ũshek. \\
\hline 76 & angun & $\ldots$ & aiño & .... & manyo & $\ldots$ & kajong & $\ldots$ & abēru ... & ... & adufü & .... & wāēmon. \\
\hline 77 & kēpé & $\ldots$ & kui ... & .... & kñōé & $\ldots$ & kuo .... & $\ldots$ & othio ... & .... & nidiēmi & $\ldots$. & nānăge. \\
\hline 78 & kürēé & . & kur .. & $\ldots$. & kur ... & $\ldots$ & nalalakujo & ... & aluango & ... & wām & .... & ũyăd. \\
\hline 79 & angit $\gamma \mathrm{m}$ & . & oñgin & $\ldots$ & onget & ... & kalim .... & $\ldots$ & engeyo & ... & nimbēka & $\ldots$ & wāakăn. \\
\hline 80 & akorok & $\ldots$ & kalok & $\cdots$ & kakorok & $\ldots$ & kabek.... & $\ldots$ & urumo & ... & injirtu & .... & domabi. \\
\hline 81 & kēnıa & .... & üp .... & .... & up .... & ... & nām .... & $\cdots$ & ting $\ldots$. & $\cdots$ & fīudădu & $\ldots$ & kāt. \\
\hline 82 & añ̄inà & .... & ngatīn & .... & moun & ... & ngolal.... & $\cdots$ & wücho ... & .... & dubadu & $\therefore$ & adāl. \\
\hline 83 & aūchongim & n.... & aupiēk & .... & ūpi .... & $\cdots$ & pièk .... & $\cdots$ & amatho & .... & bishanduk & & ap. \\
\hline 84 & ama & $\ldots$ & ongēm & $\cdots$ & äm .... & ... & wām .... & $\ldots$ & achamo & ... & nyādū & .... & sổrtōam. \\
\hline 85 & epēsien & .• & ngebarke & .... & keporien & .... & kubwar & ... & w akedo & .... & walola & .... & narlirhai. \\
\hline 86 & yeiya & $\cdots$ & sĭghan & $\cdots$ & èat .... & $\cdots$ & - & & tem .... & $\cdots$ & kñpi & $\ldots$ & eame. \\
\hline 87 & กิū .... & .... & öi ..... & .... & āoi .... & ... & buriokwalish & $1 \ldots$ & matek ... & 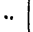 & & & ibadagiahe. \\
\hline 88 & karan & $\cdots$ & kolokol & $\cdots$ & namnyum & $\ldots$ & kual ... & $\cdots$ & maber ... & .... & wãndiko & $\cdots$ & wachabanyahe. \\
\hline 89 & mongun & ... & mongun & $\cdot$ & amal & .. & kabehıkucho & $\cdots$ & pispio ... & .. & hūrisi & $\ldots$ & năksō. \\
\hline 90 & njomōt & $\ldots$ & mutia & $\ldots$ & njomutio & $\ldots$ & mūimūt & . & mosmos & .... & linnijen. & $\ldots$ & aȳūsō. \\
\hline 91 & nyatel & $\ldots$ & tokonsale & - & nyalel & $\ldots$ & tombo kiu ar & .. & mańum & ... & dêdi & .. & akoienye. \\
\hline 92 & karām & $\ldots$ & kararan & $\ldots$ & kararan & ... & - & & mat;er... & .. & tănsā & .... & watalmonte. \\
\hline 93 & ēya ... & $\ldots$ & sorin & $\ldots$ & $\overline{\mathrm{e}} \boldsymbol{a} . . .$. & .. & - & & marach & ... & hӣmā & $\ldots$ & walıunyei. \\
\hline 94 & perir & $\cdots$ & periek & .. & perin & . & 一 & & masulnali & .... & dima & $\ldots$ & พasie. \\
\hline 95 & lel .... & $\ldots$ & lēlek & . & Ièl & .. . & - & & marachar & .... & äti .... & .... & wāādu. \\
\hline 96 & toi .... & $\ldots$. & tuek & . & toi. & & - & & lateng.... & .... & kürach & $\ldots$ & wamedoiye. \\
\hline 97 & weiwei & .... & arareita & $\cdots$ & sochige & $\cdots$ & - & & lateng.... & ... & gănālě & $\cdots$ & àkhtār. \\
\hline 98 & $\overline{\mathbf{a}} \bar{u} \mathbf{l} \ldots . .$. & .... & koliōl & .... & āoi ..... & $\ldots$ & 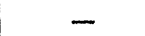 & & matek ... & .... & jăbā & $\ldots$ & hōgbuleiye. \\
\hline 99 & akong & $\cdots$ & ageuge & $\ldots$ & akenge & .... & agenge & .... & acheli.... & .... & tāka & $\cdots$ & met. \\
\hline 100 & adeng & $\ldots$ & aieng & $\cdots$ & aeng & .... & aien .... & .... & ario $\ldots$. & .... & $\operatorname{lam} . .$. & $\cdots$ & lăba. \\
\hline 101 & somok & .... & somok & $\ldots$ & samok & .... & samok & .... & adek ...: & .... & sâdı ı & $\cdots$ & sadhe. \\
\hline 102 & naoñgon & .... & añwan & $\ldots$ & oñwan & ... & anwan & ... & ongweni & ... & afur & .... & āfăr. \\
\hline 103 & ekān & .... & mūt.... & $\cdots$ & müt & $\cdots$ & muti & ... & abich .... & ... & shān & $\ldots$ & shăn. \\
\hline 104 & akankapei & $\ldots$ & ilo ..... & ... & lo $\ldots$. & $\ldots$ & mutwakenge & .. & auchiel & ... & jā ... & $\ldots$ & lēh. \\
\hline 105 & isāp & ... & tisăp & $\ldots$ & tisup & $\ldots$ & mutwaien & & aboro .... & $\ldots$ & torba & $\ldots$ & todăwī. \\
\hline 106 & tine & .... & sisit..... & .... & sisēk & .... & nutwasomok & & abereo & & sadēt & $\ldots$ & sidit. \\
\hline 107 & sokol & $\ldots$ & sokol & $\ldots$ & soghor & .... & rutuan & ... & luedoakachel. & & Eăgūl & $\ldots$ & sāgāl. \\
\hline 108 & năman & .. & tomon & ... & āmun & $\ldots$ & tomon .. & .. & apar .... & $\cdots$ & kūdăn & $\ldots$ & tomon. \\
\hline
\end{tabular}

